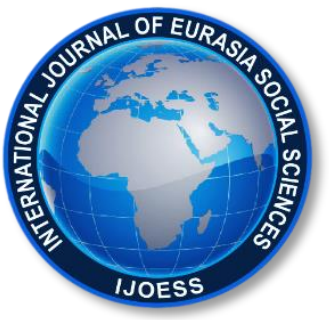

International Journal of Eurasia Social Sciences

Vol: 11, Issue: 40, pp. (341-357).

Article Type: Research Article

Received: 05.12.2019

Accepted: 13.05 .2020

Published: 07.06.2020

\title{
THE RISE OF POPULISM AND INTERNATIONAL SECURITY: POPULISM IN THE UK AND US
}

\author{
i. Aytaç KADIOĞLU \\ Assistant Professor Dr., Adıyaman University, Turkey, aytac@aytackadioglu.com \\ ORCID: 0000-0001-7957-0900
}

\begin{abstract}
The rise of populism is a global issue which causes a prominence of populist parties throughout the world. The article analyses the impact of populist politics on international security strategies of sovereign states in contemporary politics. It assesses the influence of populism through two major aspects: nationalism and immigration. The rise of nationalism is assessed through the victory of Donald Trump in the US, and the Brexit campaign in the UK. The main issues for refugees are investigated through immigration to the UK, and the US administration's plan to build a wall on the US-Mexico border to stop immigrants to cross the border illegally. While these aspects have been national issues at the beginning, they turned into international crises short after their inception since these issues have affected the national and international security concerns of these states. Therefore, the article argues that the rise of populism has a direct influence on international security strategies of these powers. It also argues that the rise of populism is related to the rightwing populism and decisions made by populist leaders of the world. It uses the ideology of populism to understand the impact of these aspects on international security. It assesses these complicated issues through official statements, speeches of leaders of the UK and US, and reports published by the UK government and US administration and international organisations to understand whether populist policies of the two administrations triggered their security concerns.
\end{abstract}

Keywords: Populism, international security, nationalism and immigration, Trump, Brexit. 


\section{INTRODUCTION}

The use of populist rhetoric is globally on the rise over the last two decades. Political agents have adopted different populist agendas to increase their public support. The increase in the populist arguments on national and international security is one of the most prominent issues in global politics. Particularly, the UK and the US witnessed enormous changes in political decisions towards nationalism. Therefore, this article aims to understand the impact of populist politics on the security concerns of these two great powers of the world.

Populist politics and the use of populist arguments in world politics has gradually attracted the attention of researchers of social sciences since the end of the World War II (Littlefield, 1964: 50; Pollack, 1960: 480; Shils, 1956: 98). While it is difficult to affiliate populism either left or right-wing politics, populism can emerge through different ideological perceptions under both political directions. While left-wing populism focuses on the rejection of large corporations and their allies, right-wing populism adopts generally anti-immigrant policies and pursues strong control mechanisms. Populism does not have a specific form which appears through different political decisions and ideologies, economic, psychological and sociological dimensions in different states and terms (Güher \& Açıkses, 2019: 131). For example, while Peru's neoliberal economics was criticised for populist decisions in the 1990s, Venezuela's socialist programme was also claimed to be an example of populism in the 2000s (Mudde \& Kaltwasser, 2017: 8-9). Particularly, the right-wing populism is on the rise in the 2010s, which appears through nationalism with a particular focus on a state's own people, and nation (Muddle, 2004: 549). Immigration is another critical issue which is frequently used by politicians in a negative meaning (Brown, 2013: 290; Diamond, 1966: 156; McLaren \& Johnson, 2007: 709). The article assesses the two issues to comprehend the complex relationship between international security and populism: nationalism and immigration.

This research relies on various cases which demonstrate populist decisions of the two great powers of the world. However, it does not claim to represent every populist policy or decisions. The article analyses official statements and press releases of the leaders of the UK and US. It also assesses official reports published by the UK and US, and international organisations. These specific cases are selected intentionally because populist political leaders of these states put international security at the top of their agenda. The article intends to explore the complex relationship between international security and populism. To explore this relationship, it emphasises on populist politics of these two states in the 2010s. While Trump's victory in 2017 is the milestone for populism in the US, the Brexit campaign of 2016 had a similar effect on populism in the UK. A number of cases of populism have been selected for the analysis, including 'Great Wall of Trump', fair or free trade, Islamophobia of the Trump administration, and 'vote leave, take control', anti-immigration policies with regards to the Brexit campaign and Islamophobia of the British government.

Populism and the support of society for populist politics are on the rise in the contemporary world. However, populist decisions differ from one state to another. For example, the sources of support for populism in the UK and US differ from each other. The wealthy people in the UK were more likely to vote against Brexit than their US counterparts were to vote against Trump (Gusterson, 2017: 212). Despite differences on the sources of 
support at the grassroots level, the societies in the UK and the US share similar concerns in the political arena, especially between diverse nationalist-populist movements in different aspects: negative reactions against immigrants, especially Muslims (Evans 2012: 21-23; Makovicky 2013: 79; Shoshan 2016: 30); an attack to international organisations, for example, the European Union (EU), North Atlantic Treaty Organization (NATO), United Nations (UN) and World Trade Organization (WTO) (Eriksen 2016: 488; Shore 2016: 489-490); a claim that working class is not well represented by traditional leftist parties in politics (Evans 2017: 215; Gaillard-Starzmann 2006: 188; Jansen 2016: 496; Kalb 2009: 207; Walley 2017); an aspersion of cosmopolitan elites that calls for returning to the tradition of the state (Knight, 2017: 238). These aspects are important concerns of the present article.

The article is organised as follows: The first section describes major aspects and the ideology of populism. The second section has a twofold analysis: first, the populist politics of the Trump administration is evaluated through specific events. Second, the right-wing populism in the UK is examined through the Brexit campaign and other decisions of the British government. The last section concludes that focusing more on international security is a clear sign of populist politics in the world.

\section{POPULISM AND ITS IDEOLOGY}

Populism is a contested term and there is no consensus on the meaning of this term. As Kazin (2019) argues, populism is a contested and ambiguous approach which utilises different principles, styles, political strategies, and marketing tool. In fact, populism has many different components and descriptions. Nye successfully brings different definitions together. He (2019: 12) notes that populism is 'a vague word with a lot of baggage, but its common denominator is resentment of powerful elites'. Although there is no universally accepted definition of populism, this term is used the idea of 'the people' as opposed to 'the elite' which presents populists.

The term populism is usually used interchangeably with 'demagogy' to describe the negative senses of politics that involve encouraging too simple solutions to complicated problems in a highly emotional situation (Mudde, 2004: 542). It is also used in the political arena against others to discredit opponents (Canovan, 2004: 243; Stanley, 2008: 101; Mudde, 2017: 2). This approach in the political arena is criticised mainly because it describes opportunistic decisions in politics to please voters instead of well-thought, planned, and insightful decisions (Mudde, 2004: 542). Examples include political parties to lower taxes before elections, to promise commitments that cannot be afforded by governments, and to instigate nationalist and patriotic feelings in society for their benefits.

Laclau's threefold definition of populism is a strong formal-structural approach which comprises 'the formation of an internal antagonistic frontier separating the "people" from power', 'the formation of an equivalent pattern between popular demands which are excluded from the decision-making process by the government in power, and "the people" represents unrepresented' and 'externalised community in society who are seen the only legitimate group of people' (Laclau, 2005: 110). 
In terms of the ideology of populism, Mudde and Kaltwasser (2017: 5) state that populism is a criticism of formation and adulation of society. Further, Stanley (2008: 96) describes the ideological perspective of populism that it is an antagonistic relationship between two sides: the elite and the people. While 'the elite' describes an adversarial relationship with the society in the context of political, economic, media and cultural dimensions (Canovan, 1981: 295), 'the people' is defined to be a homogenous and virtuous group (Mudde \& Kaltwasser, 2017: 9). Therefore, the main idea of populism is anti-elitism and to prevent an elitist political, social, cultural and economic programme. The existing populism literature examines the people in three different ways: First, the people are sovereign and so they determine political decisions in democratic states. Second, the people define a socio-economic or class-based category which shares popular or cultural traditions. Third, the people are equal to the nation in ethnic and civic meanings (Mudde \& Kaltwasser, 2017: 10-11). Although the vast amount of the definitions of 'the people', how the populist approach is directed towards the people is largely criticised. Even though populist leaders introduce themselves part of the people and so they are people's representative, most of these leaders are from elite strata in society. For instance, Jörg Haider, Pim Fortuyn and Silvio Berlusconi well represented their political and economic elite much before the initiation of their political career (Mudde, 2004: 560).

Populism is also labelled as a 'thin ideology' or 'thin-centred ideology' which is blamed for being insufficient to explain complex changes in society. Thus, it is difficult to compare it with 'thick-ideologies', such as liberalism, socialism, constructivism and fascism which present ideas about the transformation of society (March, 2007: 64). Populism is also defined as peculiar negativism which has different characteristics, e.g. anti-semitic, anti-urban, xenophobic and anti-capitalistic (Ionescu \& Gellner, 1969: 4). Considering this, populism is mostly combined with different forms of liberalism, socialism, nationalism, conservatism etc. (Albertazzi \& McDonnell, 2008: 4). Besides, it is also suggested that populism as a thin-ideology presents a complementary ideology and does not have too many points overlapping with thick-ideologies (Stanley, 2008: 107).

In theory, populism should be a moralistic ideology instead of a programmatic one (Mudde \& Kaltwasser, 2017: 6). However, in practice, populism is seen as a tool to divide people 'friends' and 'foes' which the latter is seen not only an enemy but also an evil. Thus, the people should be as pure as possible and any division or prioritisation between different groups in society should be refused (Mudde, 2004: 544).

Populist ideology cannot be restricted with either left or right-wing ideology as it can be combined with both ideologies. Left-wing populism primarily focuses on institutional representation to the opposition in a society, and so providing social inclusion, justice and collective acknowledgement (Kioupkiolis, 2016: 103-104). Muddle (2004: 543) describes populism as an ideology which considers society totally separated between 'the corrupt elite' and 'the pure people', and that assumes that political decisions should be based on the general will of the citizens. Right-wing populism defends 'the people' against 'the elite' in theory. However, in practice, right-wing populism is utilised to define political parties and groups that are mostly against refugees, the Islamic world and that have Euroscepticism (Sharpe, 2017). 
Right-wing populism is also associated with several ideas such as neo-nationalism, protectionism, opposition to immigration, anti-environmentalism and anti-globalisation (Greven, 2016: 2; Lowry, 2017; Movsesian, 2016; North, 2017; Taub, 2016). The rise of nationalism and the question of immigration are selected to examine the influence of right-wing populism on security issues. The rise of the election of nationalist leaders, such as Donald Trump in the US, Theresa May (then Boris Johnson) in the UK, the rise of far-right leader Marine Le Pen in France, and many others in Europe and the rest of the world makes this question very important due to the influence of these leaders in global politics. How has the US policy changed after the election of Trump? What is the relationship between right-wing populism and security decisions in the US, namely nationalist decisions on visa allowance and the wall between the US and Mexico? Why has the 'leave' campaigners in Brexit won the election? How has neo-nationalist politics affected this outcome? These questions are investigated in this paper to help understand the rise of populism and its effects on international security.

\section{POPULISM AND INTERNATIONAL SECURITY}

\section{Populism in the USA}

The US presidential election of 2016 witnessed populist political stances. Trump has been attacked by socialists, social liberals, republicans and conservatives for being a polarising figure to become the president of the US. His populist position has been criticised through his point of view, political attitude and world view:

His rhetoric peddles a mélange of xenophobic fear tactics (against Mexicans and Muslims), deepseated misogyny, paranoid conspiracy theories about his rivals, and isolationist 'America First' policies abroad. His populism is rooted in claims that he is an outsider to D.C. politics, a self-made billionaire leading an insurgency movement on behalf of ordinary Americans disgusted with the corrupt establishment, incompetent politicians, dishonest Wall Street speculators, arrogant intellectuals, and politically correct liberals (Inglehart \& Norris, 2016: 5).

The ideology of populism promotes mono-culturalism as opposed to multiculturalism and prioritises national self-interest against international cooperation. The situation in the US has been similar since the Trump administration intends to close borders to refugees and those who desperately need help. Therefore, Trump's decisions on mono-culturalism are related to both nationalism and immigration. Trump's statements are seen clear examples of racial resentment, lack of tolerance to foreign citizens, isolation of other nations, mistrust to others, the forceful leadership, aggressive politics and racial and anti-Muslim language (Inglehart \& Norris, 2016: 7).

Trump's political position was clearly stated during his presidential election campaign. In many of his speeches, Trump illustrated a nationalist and populist profile focusing on the rise of America again in the world politics and economics, and international security of the US:

Populist movements, leaders, and parties provide a mechanism for channeling active resistance. Hence Trump's slogan 'Make America Great Again' - and his rejection of 'political correctness' appeals nostalgically to a mythical 'golden past', especially for older white men, when American society was less diverse, U.S. leadership was unrivalled among Western powers during the Cold 
War era, threats of terrorism pre-9/11 were in distant lands but not at home, and conventional sex roles for women and men reflected patrimonial power relationships within the family and workforce (Inglehart \& Norris, 2016: 16).

Therefore, his political stance can be labelled pro-nationalism which became popular during the presidential campaign. This is in line with Rahn's (2019: 356) argument as he argued that Trump's campaign triggered racial resentment among whites which played an immense role in increasing support for Trump. Particularly, Trump's political discourse is highly populist which focuses on anti-immigration policies, protectionism on trade and nationalist decisions. Trump's populist politics on nationalism depends upon several aspects. His decision on tariffs on Chinese exports to the US was announced as for the benefits of the national interests of the US. According to this policy, up to 45 percent tariff will be applied to Chinese products. The policy was followed by 35 percent tax on cars crossing the Mexican border. This protectionist and populist approach has been repeatedly stated during the election campaign of Trump. President Trump argues that this approach will provide high salary jobs back to the US as he said: 'We are going to beat all of these countries that are taking so much of our money away from us on a daily basis. It is not going to happen anymore' (Trump, quoted in Becker, 2016). This is a clear example of Trump's 'fair trade', not 'free trade' policy.

To secure the American nation's future is one of Trump's main rhetoric since his first political statement. Therefore, those who are fearful of terrorist attacks are more likely to support his political stance. He argued that he would destroy the Islamic State without explaining how and so, no one can mess with Americans through a military 'so big, and so strong, and so great' (Trump, quoted in Becker, 2016). According to his belief, the US should be secured from any threats including Muslims. Hence, he talked several times to ban Muslims from entering the US. Islamophobia is seen as one of the national politics of the Trump administration as a way to prevent any security threat to the US.

Considering wars and conflicts throughout the world, economic difficulties, authoritarianism, lack of democratic rights and disrespect to believes, immigration from undeveloped and developing countries to developed countries has increased in the last few decades. Since his election campaign, Trump has always been against immigration to the US which he believes will affect the living conditions and economy of the US negatively. Trump explained why he is against immigration during his early election campaign in 2015 :

When Mexico sends its people, they are not sending the best. They are not sending you, they are sending people that have lots of problems and they are bringing those problems... They are bringing drugs, they are bringing crime. They are rapists and some, I assume, are good people, but I speak to border guards and they are telling us what we are getting (Trump, quoted in Gamboa, 2015).

He stated that this issue caused many security concerns for the US administration and American people on border security. By referring the border issues, he said that the US has no protection and no competence due to the people coming from the south of the US (Trump, cited in Gamboa, 2015). He, therefore, legitimised the US's national and international security concerns and claimed that he would build a wall in the border of Mexico if he was elected: 'I would build a Great Wall, and nobody builds walls better than me, believe me, and I will build 
them very inexpensively. I will build a great, great wall on our southern border and I will have Mexico pay for that wall, mark my words' (Trump, quoted in Gamboa, 2015).

Another issue with Trump's immigration policy is that he suggested deporting eleven million undocumented immigrants. Although the immigration bill has been discussed for a long time, the decisions between the Obama and Trump administrations are clearly distinctive on the immigration issue. While the Obama administration followed a more global political approach which embraced the inclusion of a humanistic approach, the Trump administration has prioritised the American nation. It can be seen through Trump's blame to the Obama administration that his predecessor caused millions of refugees to enter the US illegally due to executive action on immigration. He criticises that the action would shield millions of refugees from deportation and give official permission to work in the country (Trump, cited in Gamboa, 2015). To suggest revoking of the birth-right citizenship of the undocumented immigrants is another populist policy of the Trump administration. As North (2017) states, anti-globalist politics is a clear indication of nationalist populism which is in line with Trump's political stance.

The last issue with regards to immigration is to travel ban into the US for citizens of seven countries in 2017: Syria, Yemen, Iran, Iraq, Libya, Somalia and Sudan. The sign of this executive order of Trump is directed to control wide-ranging immigration in the country. Trump's plan is to suspend potential refugee arrivals from these countries which are named 'countries of concern' by a rule of law passed by a Republican-led Congress (Goodman, 2017). This is directly related to international security of the US because this populist policy was a matter of the threat. The Congress passed this rule of law in December 2015. This rule of law also affected those who were eligible for the Visa Waiver Program (VWP). The VWP allows the citizens of 38 countries to enter in the US without a visa for 90 days. The US restricted the citizens of these countries if they had visited one of these seven countries since March 2011. This was because these specific countries were identified as harbouring terrorist groups and labelled 'safe haven' for terrorists (Goodman, 2017). The VWP and Terrorist Travel Prevention Act were signed in 2015 after the terrorist attacks in Paris during the Obama administration. However, the scope of these programmes became a much broader law during the Trump administration. As these two policies affected not only those who were eligible for the VWP but all citizens travelling from these seven countries, it demonstrates how the Trump administration pursued pro-nationalist politics. 


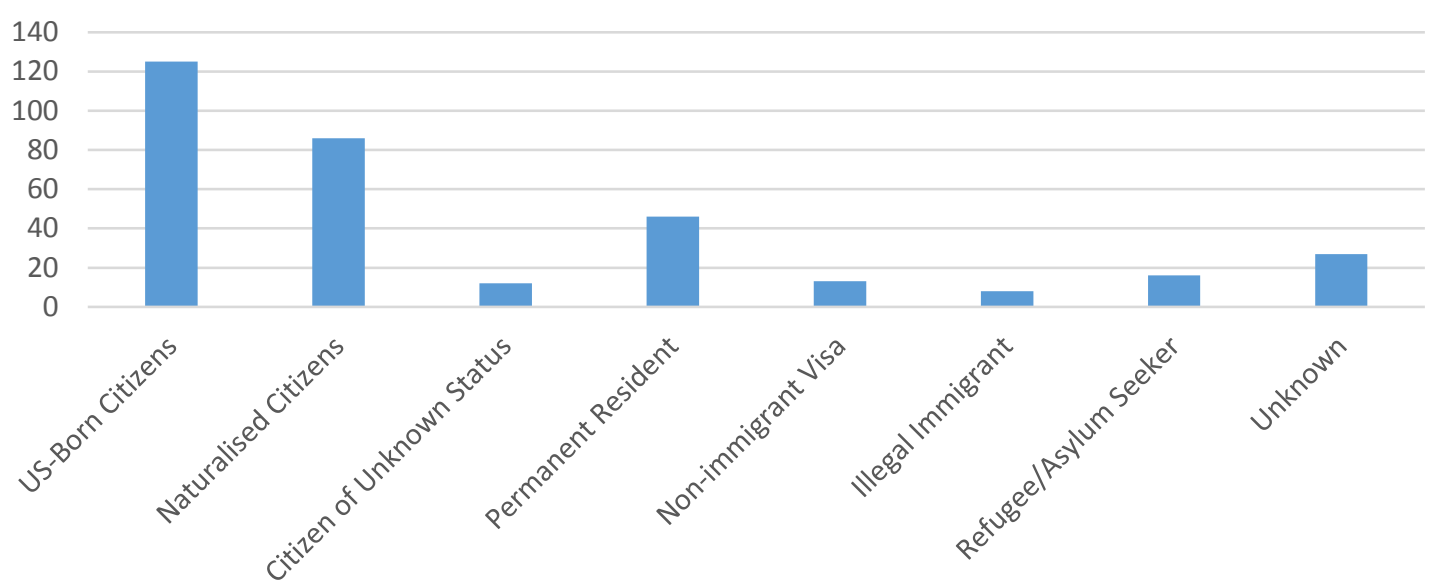

- Terrorism Related Cases

Figure 1. Terrorism Related Cases since $9 / 11$ in the US (BBC, 2017)

Figure 1 illustrates terrorism-related cases between September 2001 and March 2017. The US administration announced the 'war on terrorism' declaration and took terrorism centre stage in the US's national security policy. This policy was also meant to follow a more nationalist approach considering that the $9 / 11$ attacks were organised by non-US born citizens. However, Figure 1 demonstrates that a majority of terrorism cases in the US were organised by US-born citizens. While the Trump administration asserted that the immigration issue and asylum seekers cause violence and terrorism in the US, the statistics suggest that only 37 of all terrorism cases were organised by immigrants and asylum seekers. In contrast, 211 of 333 cases were charged with or died engaging with radical religious terrorism. Therefore, Figure 1 proves that the citizens of these seven countries are not the biggest threat to the US. The travel ban for specific citizens will not likely to reduce the level of terrorism in the US.

\section{Populism in the UK}

Much before the Brexit campaign, the Eurosceptic and populist right-wing party, the United Kingdom Independence Party (UKIP) and its leader Nigel Farage was supporting the UK's withdrawal from the EU. Farage defended the importance of identities as opposed to global trends. He stated that "What we have tried to do in Europe is go against all the trends globally" because "globally, the world is breaking down into smaller units" and Europe does not comprehend this change as it "complete lack(s) of understanding of how human beings operate" (Farage, quoted in Shuster, 2017). UKIP's rising support in the UK led the party to argue for 'opportunity for real change in our politics' (UKIP, 2015).

The Conservative Party added manifesto in its 2015 election campaign and promised that the party will go to a referendum of in-out decision of the EU by the end of 2017 (Conservative Party Manifesto 2015: 32). On June 23, 2016, the UK referendum of the EU membership took place and the majority of the UK citizens voted to leave the EU (Table 1). The contested referendum was seen as the rise of populism with regards to control immigration 
and to reclaim national sovereignty from EU institutions. This is in line with the anti-immigration and anti-trade attitude in the US, both the leaders of the UK and US think that they are losing control of their country as a result of globalisation.

Table 1. 23 June 2016 Referendum on the Brexit (The Electoral Commission, 2016)

\begin{tabular}{ccc}
\hline Voted & People & Percent \\
\hline To remain & $16,141,241$ & $48.1 \%$ \\
\hline To leave & $17,410,742$ & $51.9 \%$ \\
\hline
\end{tabular}

The major reasons for Brexit referendum are the policies on migration, free movement of the EU citizens, regaining the control of their politics from the EU institutions, abolish financial aid to EU institutions and candidate members. In terms of the migration issue, as the UK is outside of Schengen borders, the UK has much more control of its borders compared to other EU states. However, as Alden (2016) argues, even though the UK economy is growing and has low unemployment, the Great Recession in the world reflects in the UK through the reactions to refugees and the government policies on immigration. These reactions merge together with the fear in the society that they would lose their job if more refugees are welcomed by the UK institutions. In reality, the British economy successfully absorbs new immigrants and grows faster than in other European countries. However, the populist politics took place in the country which triggered the rise of nationalist politics, and fear for and hate of immigrants in the UK.

The Brexit campaigners' ads are a clear example of nationalism and the refugee crisis. The populist political stances rely on the campaign 'vote leave, take control' which were promoted through several claims: $£ 350$ million a week is sent every week to the EU institutions, Turkey would be a member of the EU and Turkish citizen will soon come to the UK if the UK does not leave the EU, and the National Health Service (NHS) will be stronger if the UK leaves the EU. The current Prime Minister Boris Johnson is one of the strongest Brexit campaigners since the beginning of the campaign. He has been influential in making the EU an element of fear with full of bumbling bureaucrats and drew optimistic pictures for society. In addition, Nigel Farage, the UKIP leader has been the face of the Brexit idea. He did several things for the UK to leave the EU: "Motivate and turn out the third of the voters who shared his implacable hostility to the EU and his alarm over excessive immigration. When the UKIP was founded in 1993, Brexit was a crankish obsession. Over the last 20 years, Farage has done more than anyone to turn it into reality" (Colvile, 2016).

The problem with regards to immigration in the UK is that the country was the least affected one from the current refugee crisis compared to other European countries. Arguably, it is due to the geographical location of the country. However, the right-wing populism agitated the issue and caused the nationalist idea to take action which caused the decision to leave the EU. The great refugee flow to especially eastern European countries from Syria, Afghanistan and North Africa created an international security issue for these countries. The control of their borders became their crucial concern especially after the Paris attack of November 2015 and the Brussels attack of March 2016 
The populist stance in the UK fuelled anti-European and anti-immigration politics through the decisions of former Prime Minister David Cameron's call for the Brexit referendum. Since then, the political condition of the UK has been unstable due to the British government's conflict with the EU leaders, the resignation of Cameron, prospects of the disintegration of the UK, uncertainty in global trade and financial markets, and hate speeches resulting in attacking immigrants in the country (Dennison, 2016). Therefore, it can be said that the rise of populism in the UK has hit the country due to mainly nationalist and anti-immigrant policies. These policies, undoubtedly, aim to secure the borders of the UK and so securitising policies of the country. Further, there is a bilateral relationship between the two policies and other national politics in the UK, such as economic indicators, trade and health system. The two sides constantly affect each other since the Brexit campaign of 2016. In addition, according to March (2019: 64), the Brexit referendum and 'take back control' slogan illustrated that high people-centric rhetoric low anti-elitist discourse created were the keys of populism in the UK.

Furthermore, the British government has been accused of the reasons for the Brexit campaign. Although it is argued that the UK is affected heavily of the immigration issue due to the membership of the EU, it is also suggested that the UK is the least affected country from the results of immigration. According to James McBride, editor at the Council of Foreign Relations, the UK's vote to leave embodies irony considering the limited influence on its economy and politics:

There is a lot of irony in this, since the UK is outside of Schengen and has a lot more control over non-EU migration. And because it is isolated on an island it hasn't faced anything like what the rest of Europe has faced in terms of dealing with the flow of refugees from the Middle East and from North Africa. The UK has had trouble controlling free movement from within the European Union, but that's only a part of what the Brexit campaign was focused on. If you actually look at the ads that were run, they drew very clear links to the refugee crisis that is facing Europe (McBride, quoted in Alden, 2019).

In fact, the UK is not part of the free movement for those who have the Schengen visa and is able to prevent the refugee flow from the Middle Eastern, Asian and North African countries thanks to its geographical advantages. However, the electoral victory of Boris Johnson in the national election of December 2019 illustrates that populist politics in the UK has a great influence on political decisions. 2019 Conservative Party Manifesto is the clear evidence of this policy: "Get Brexit Done: Unleash Britain's Potential". The manifesto argues that the EU has affected the development of the British market and stable UK politics in several different manners which are illustrated in Table 2:

Table 2. Main Aspects of the Conservative Party Manifesto 2019 (Conservative Party, 2019)

\begin{tabular}{cr}
\hline Aspect & Policy \\
\hline Nationalism & End division and deadlock in the UK politics \\
\hline Nationalism & Restore confidence to UK businesses \\
\hline Job Market & Increase investment into the UK \\
\hline Nationalism/Immigration & Focusing on the priorities of the British people \\
\hline Health Sector & Funding the NHS \\
\hline Immigration & An Australian-style points-based system to control immigration \\
\hline
\end{tabular}


The Conservative Party's election manifesto illustrates that several policies are related to nationalism and immigration at the election campaign (Table 2). The victory of Johnson at the national election shows the support of the society towards nationalist and anti-immigrant policies. The populist politics of the Conservative Party helped increase its votes from 318 seats in 2017 national election to 365 seats in 2019 national election. In contrast, the anti-Brexit politics of the Labour Party did not help increase its votes as the party received 262 seats in 2017, and 203 seats in the 2019 national election (BBC, 2019). This change demonstrates the support for nationalist politics of the UK society. The increasing support for the Conservative Party was affected by populist election campaigns through the use of provocative language, and protectionist and pro-nationalist advertisements. For example, Brexit campaigners asserted that Turkish citizens would come to the UK if the Brexit was not accomplished, and the UK would pay to the EU $£ 350$ million per week but not receiving any fund from the EU institutions.

\section{THE RISE OF POPULISM AND ITS CONSEQUENCES}

The right-wing populism of the Trump administration and the British government is viewed through nationalist, anti-globalist, anti-immigrant and security-based decisions. Several aspects are significant to explain the reasons for the influence of populist politics on national and international security concerns of the two states. First, nationalist populism in the UK and US has grown through different aspects: While the question of global recession raised the economic conditions of the American and British citizens as opposed to other nations, globalisation is viewed as the threat to protect the wealth of their nation since it seems as a result of losing their jobs. In this context, it is difficult to differentiate nationalist policies from the migration issue in both countries. The rightwing populism has mostly combined these two issues in the discourse of political campaigns and the statement of politicians in the UK and US.

Second, border security is an important issue for both the US and UK. The criticism in the US stemmed from losing control of the borders, which was viewed as the reason for millions of people illegally entering the US via the Mexico border. It is a general perception that American citizens are tolerant and supportive of immigration if the US administration persuades them the issue is under the control. Thus, the question for American people is whether the government keeps the issue under control. Martin (2014) states that the US received millions of refugees in the 1990s and 2000s mainly from Mexico which created a perception that the US government lost the control of the border. Since then, the US government has formed a process of border security and has been very powerful to bring the borders under control (Alden, 2016). Nevertheless, politics remained behind reality and populist politics used this phenomenon as a way of political success (Roberts et al., 2013). The criticism in the UK was the fear of receiving more refugees which would hit their economy. This fear had a peak through the Brexit campaign in which the immigration issue was illustrated a security and economic threat for the UK nation. The leave campaigners of Brexit focused on the border security but at the eastern borders of the EU. The nationalist and populist stances are that the UK has lost control of their borders as the UK politicians cannot 
decide who is coming in the country and who is not. This stance is announced as the loss of sovereignty and this cannot be tolerated (Alden, 2016).

Third, the populist decisions in the UK and US politics were supported by the two societies as the populist speeches and positions of the Conservative Party in the UK and the Republican Party in the US increased their votes in the last few years. This demonstrates that the rise of populist politics triggers societal reactions against major issues such as globalisation and immigration. While the perception towards globalisation has been determined by nationalism, free-market economy, unemployment and other financial concerns, the immigration issue has emerged through border security, terrorism, travel restrictions, reactions against neoliberal policies and Islamophobia.

Last, there are some country-specific issues in the two cases. The US administration and UK government presented traditional right-wing populism which is driven by fear of the other. While political leaders of both countries show refugees as a threat to their welfare and peace, they have some differences in their populist politics. The Trump administration sees globalisation and free trade system as enemies of the US since white Americans are illustrated the victims of globalisation (Lamont, 2017: 153). The Trump administration's campaign slogan 'Make America Great Again' was clear evidence of his ambition to make the US unrivalled in global politics. He also portrayed a nationalist approach during his campaign. His presidential election speech proves this position: 'This is not simply another four-year election. This is a crossroads in the history of our civilization that will determine whether or not we the people will control over our government' (Trump, quoted in Smith et al., 2019).

The Conservative Party followed a populist election campaign as David Cameron promised a referendum on remaining or leaving the EU. According to Cameron, "'disillusionment' with the EU was at an all-time high", and thus, they will ask the citizens to carry on accepting the European settlement over which they had little choice (Cameron, quoted in BBC, 2013). However, unlike Trump, Cameron did not pursue a pro-nationalist campaign. He said that 'I believe that, despite its faults and its frustrations, the United Kingdom is stronger, safer and better off by remaining a member of the European Union. Better off? Certainly.' (Cameron, quoted in Haigh, 2018). However, once he re-elected, he put his promise in the party's manifesto by calling a referendum and stepped down after Brexit supporters won. While the Conservative Party, won the general election in 2015, the Eurosceptics in the Conservative Party and other parties consolidated great support for the Brexit campaign by using nationalist, anti-immigrant and anti-EU politics. In addition, Trump's electoral campaign was a reaction against the liberal world order. However, the Brexit campaign in the UK was a reaction against the political power of the EU institutions over British politics, the number of economic aids to the EU each year, and the EU's policies towards immigration and refugees in regard to security concerns. These are all seen as threats over the prosperity of the UK. As a result, both countries experience the rise of populism and embraces the high degree of support at the two societies. 


\section{CONCLUSION}

The article has argued that the US administration and the UK government have witnessed right-wing populism through pro-nationalist and security-based campaigns by standing against immigration, globalisation, free trade and neoliberalism. These issues have been described as threats to the social and economic welfare of the US and UK. Therefore, the Conservative Party in the UK defends the exit of the UK from the EU as they believe that the UK government provide billions of euros each year for the institutions of the UK, but in return faces border security problems, immigration from the third countries and the lack of control of the EU institutions on security issues. The Trump administration's policy has been similar. The populist policy which led Trump to win the presidential election is maintained by his administration and Trump thinks that to close the borders to foreign nations will reduce the security threat directed at the US even though the numbers do not support his argument.

The rise of populism has affected international security concerns of the US and UK in regard to immigration, border security, terrorism and crime. Trump's plan to build a wall on the US-Mexico border was introduced as a national emergency to secure the border. As explained earlier, Trump asserted that terrorists and drug dealers entered the US illegally via the US-Mexico border. Therefore, immigration and border security are seen as international security threats by the US administration. In addition, Trump's order to suspend potential refugee arrivals from seven countries called 'countries of concern' was used to prevent any potential terrorist attacks in the US. Although no link between the citizens of countries of concern and terrorism and crime in the US was found, the so-called security precaution can be seen as the Trump administration's populist stance. Similarly, the UK government and Brexit supporters had concerns on security, economy and politics. These three pillars were used together from the referendum campaign until the present time. The right-wing populism in the country overstated the refugee issue asserting that refugees cause security problems. This triggered hate of immigrants and widespread feelings of insecurity with regards to refugees. The Schengen area of the EU is another concern of British politics since the Brexit defenders believed that it affected the border security of the country. The refugee flow -especially from the Asian, North African, and Middle Eastern countries to the UK - was introduced as an international security issue. The use of refugees and immigrants by populist leaders caused the society to divide people between 'us' and 'others'. This security-based view led to the societal support for the 'nation first' policy and affected to polarise people in society.

The article has found that there has been a top-down approach in spreading populism in the UK and US. The populist decisions in the political arena in the 2010s have been supported by a majority of people in the two countries. Although it is difficult to argue that the reasons for popular support for the populist decisions are only nationalism and immigration, these two aspects are critical in determining the relationship between international security and populism. The article has argued that there is a bilateral relationship between international security and populism. While security concerns of the two states result in populist politics and rises nationalism, the support for populist stances at the grassroots level also causes the increase in the populist discourses and speeches in the two states. 


\section{ETHICAL TEXT}

In this article, journal writing rules, publishing principles, research and publishing ethics rules, journal ethics rules are followed. Responsibility belongs to the author for any violations related to the article.

\section{REFERENCES}

Albertazzi, D. \& McDonnell D. (2008). "Introduction: The Sceptre and the Spectre." Twenty-First Century Populism. (Eds.) Daniele Albertazzi and Duncan McDonnell. New York: Palgrave MacMillan. 1-11.

Alden, E. (2016). What Brexit Reveals About Rising Populism. Interviewed by James McBride. Council on Foreign Relations.

BBC (2013). David Cameron Promises in/out Referendum on EU. Accessed on April 24, 2020. Retrieved from https://www.bbc.com/news/uk-politics-21148282.

BBC (2017). Trump's Executive Order: Who Does Travel Ban Affect? BBC News. Accessed on December 1, 2019. Retrieved from https://www.bbc.com/news/world-us-canada-38781302.

BBC (2019). Results of the 2019 National Election. BBC News. Accessed on December 2, 2019. Retrieved from https://www.bbc.com/news/election/2019/results.

Becker, B. (2016). Trump's 6 Populist Positions. Politico. Accessed on September 3, 2019. Retrieved from https://www.politico.com/story/2016/02/donald-trump-working-class-voters-219231.

Brown, H. E. (2013). Race, Legality, and the Social Policy Consequences of Anti-Immigration Mobilization. American Sociological Review, 78 (2), 290-314.

Canovan, M. (1981). Populism. New York: Harcourt Brace Jovanovich.

Canovan, M. (2004). Populism for Political Theorists? Journal of Political Ideologies. 9 (3): 241-252.

Colvile, R. (2016). The Dirty Dozen: 12 People Who Brought about Brexit. Politico. June 25, 2016. Accessed on June 20, 2019. Retrieved from https://www.politico.eu/article/12-people-who-brought-about-brexitleave-remain-referendum-campaign-euroskeptics-tension/.

Conservative Party Manifesto (2015). Your Manifesto. The Conservative Party. Accessed on May 1, 2017, Retrieved from https://www.conservatives.com/yourmanifesto.

Conservative Party Manifesto (2019). Get Brexit Done: Unleash Britain's Potential. The Conservative Party. Accessed on November 28, 2019, Retrieved from https://assets-global.websitefiles.com/5da42e2cae7ebd3f8bde353c/5dda924905da587992a064ba_ Conservative\%202019\%20Manifesto.pdf.

Dennison, S. (2016). The World According to Europe's Insurgent Parties: Putin, Migration and People Power. London: European Council on Foreign Relations.

Diamond, S. (1996). Right-wing Politics and the Anti-Immigration Cause. Social Justice, 23.3 (65), 154-168.

Eriksen, T. H. (2016). Clashing Scales of Brexit. Social Anthropology 24 (4): 488-89.

Evans, G. (2012). 'The Aboriginal People of England': The Culture of Class Politics in Contemporary Britain. Focaal, 62 (March): 17-29. 
Evans, G. (2017). Brexit Britain: Why We Are All Postindustrial Now. American Ethnologist 44 (2): $215-219$.

Gamboa, S. (2015). Donald Trump Announces Presidential Bid by Trashing Mexico, Mexicans. NBC News. June 16, 2015. Accessed on September 1, 2019. Retrieved from https://www.nbcnews.com/news/latino/donald-trump-announces-presidential-bid-trashing-mexicomexicans-n376521.

Gaillard-Starzmann, G. (2006). "Regarding the Front National." Neo-nationalism in Europe and Beyond: Perspectives from Social Anthropology. (Eds) Gingrich, A., and Banks M. New York: Berghahn. 177-198. Goodman, J. (2017). US Travel Ban: Why These Seven Countries. BBC. 30 January 2017. Accessed on April 8, 2017. Retrieved from https://www.bbc.com/news/world-us-canada-38798588.

Greven, T. (2016). The Rise of Right-wing Populism in Europe and the United States. Friedrich-Ebert-Stiftung.

Gusterson, H. (2017). From Brexit to Trump: Anthropology and the Rise of Nationalist Populism. American Ethnologist 44 (2): 209-214.

Güher, E. \& Açıkses E. (2019). Intense Migration from Harpoot to America with New Documents (1870-1920). International Journal of Eurasia Social Sciences 10 (35): 130-162.

Haigh, P. (2018). Why Did David Cameron Call a Referendum on Brexit? Metro. Accessed on April 25, 2020. Retrieved from https://metro.co.uk/2018/12/11/david-cameron-call-referendum-brexit$8231803 /$ ?ito=cbshare.

Inglehart, R. F. \& Norris P. (2016). Trump, Brexit, and the Rise of Populism: Economic Have-Nots and Cultural Backlash. Faculty Research Working Paper Series. Harvard Kennedy School. Report No: RWP16-026, 152.

Ionescu, G. \& Gellner, E. (1969). “Introduction.” Populism: Its Meaning and National Characteristics. (Eds.) Ionescu, G., and Gellner, E. Hertfordshire: The Garden City Press. 1-6.

Jansen, S. (2016). North-West and South-East European Post-Fordist Affect. Social Anthropology 24 (4): $496-497$. Kalb, D. (2009). Conversations with a Polish Populist. American Ethnologist 36 (2): 207-223.

Kazin, M. (2016). Trump and American Populism. Foreign Affairs, October 6. Accessed on March 19, 2018. Retrieved from https://www.foreignaffairs.com/articles/united-states/2016-10-06/trump-andamerican-populism.

Kioupkiolis, A. (2016) Podemos: The Ambiguous Promises of Left-wing Populism in Contemporary Spain. Journal of Political Ideologies, 21 (2), 99-120.

Knight, D. M. (2017). Anxiety and Cosmopolitan Futures: Brexit and Scotland. American Ethnologist 44 (2): 237242.

Laclau, E. (2005). On Populist Reason. London: Verso.

Lamont, M., Park, B. Y. \& Ayala-Hurtado, E. (2017). Trump's Electoral Speeches and His Appeal to the American White Working Class. The British Journal of Sociology, 68: 153-180.

Littlefield, H. M. (1964). The Wizard of Oz: Parable on Populism. American Quarterly, 16 (1): 47-58.

Lowry, R. (2017). The End of Reaganism. POLITICO Magazine. Accessed on April 3, 2019, Retrieved from https://www.politico.com/magazine/story/2017/03/the-end-of-reaganism-214853. 
Makovicky, N. (2013). 'Work Pays': Slovak Neoliberalism as 'Authoritarian Populism'. Focaal, 67 (December): 7790.

March, L. (2007). From Vanguard of the Proletariat to Vox Populi: Left-Populism as a 'Shadow' of Contemporary Socialism. SAIS Review of International Affairs. 27 (1): 63-77.

March, L. (2019). "Textual Analysis: The UK Party System”. The Ideational Approach to Populism: Concept, Theory, and Analysis. (Eds.) Hawkins, Kirk A., Carlin, Ryan A. Oxon: Routledge. 49-66.

Martin, D. A. (2014). Resolute Enforcement Is Not Just for Restrictionists: Building a Stable and Efficient Immigration Enforcement System. JL \& Pol. 30: 411-464.

McLaren, L. \& Johnson M. (2007). Resources, Group Conflict and Symbols: Explaining Anti-Immigration Hostility in Britain. Political Studies, 55 (4), 709-732.

Movsesian, M. L. (2016). The New Nationalism. Online Library of Law \& Liberty. Accessed on April 10, I 2019 Retrieved from https://lawliberty.org/the-new-nationalism/.

Mudde, C. (2004). The Populist Zeitgeist. Government and Opposition. 39 (4): 541-563.

Mudde, C. \& Kaltwasser C. R. (2017). Populism: A Very Short Introduction. Oxford: Oxford University Press.

North, B. (2017). The Rise of Right-Wing Nationalist Political Parties in Europe. WUWM. Accessed on April 11, 2019. Retrieved from https://www.wuwm.com/post/rise-right-wing-nationalist-political-partieseurope.

Nye, J. (2019). Populism is Likely to Continue in the US. The International Economy, 19: 12-13.

Pollack, N. (1960). Hofstadter on Populism: A Critique of the Age of Reform. The Journal of Southern History, 26 (4): 478-500.

Rahn, W. (2019). "Populism in the US: The Evolution of the Trump Constituency". The Ideational Approach to Populism: Concept, Theory, and Analysis. (Eds.) Hawkins, Kirk A., Carlin, Ryan A. Oxon: Routledge. $350-$ 373.

Roberts, B., Edward A. \& Whitley J. (2013). Managing Illegal Immigration to the United States: How Effective Is Enforcement? Council on Foreign Relations.

Sharpe, M. (2017). The Long Game of the European New Right. The Conversation. Accessed on July 12, 2019. Retrieved from https://theconversation.com/the-long-game-of-the-european-new-right-75078.

Shore, C. (2016). Brexit, Populism, and the Anthropology of Austerity. Social Anthropology 24 (4): 489-490.

Shoshan, N. (2016). The Management of Hate: Nation, Affect, and the Governance of Right-Wing Extremism in Germany. Princeton, NJ: Princeton University Press.

Shuster, S. (2017). The Populists. Time. Accessed on December 12, 2019. Retrieved from https://time.com/timeperson-of-the-year-populism/.

Smith, D., Lewis, P. Holder, J. \& Hulley-Jones F. (2019). New Research into Donald Trump's Speeches Reveal Why the President's Scripted Brand of Populism Doesn't Come Easy. Guardian. Accessed on April 26, 2020. Retrieved from https://www.theguardian.com/world/ng-interactive/2019/mar/07/the-telepromptertest-why-trumps-populism-is-often-scripted.

Stanley, B. (2008). The Thin Ideology of Populism. Journal of Political Ideologies. 13 (1): 95-110. 
Taub, A. (2016). A Central Conflict of 21st-Century Politics: Who Belongs? The New York Times. 8 July 2016

The Electoral Commission (2016). Report: 23 June 2016 Referendum on the UK's Membership of the European Union. The Electoral Commission of the UK Government. London. September 2016.

UKIP (2015). Believe in Britain. UKIP Manifesto 2015. Newton Abbot: UKIP.

Walley, C. J. (2017). Why Did the Rustbelt Flip? Cultural Anthropology Website, January 18. Accessed on August 6, 2019. Retrieved from https://culanth.org/fieldsights/1047-why-did-the-rust-beltflip. 